\title{
Reasons to be cautious about 'well-being' in economic development (and elsewhere)
}

\author{
Matt Jenkins \\ Centre for Urban and Regional Development Studies, \\ University of Newcastle, \\ NE1 7RU, UK \\ Email: m.jenkins2@ncl.ac.uk
}

\begin{abstract}
Well-being' is currently in vogue in policy-making circles in the Global North as a way of reconceptualising 'development'. This paper argues that its appearances are misleading. While the normative force of 'well-being' is accepted, what is being offered is a technocratic and reductionist programme which collapses 'well-being' into the statistical relation of a closed set of metrics. It is argued that 'well-being' as defined is a chaotic conception; not a concrete object but an evaluative state, and so such programmes necessarily fail to measure it. Further, it is argued that 'well-being' is already considered within economic development policy and that previous development initiatives would not have changed had well-being frameworks existed alongside them. It is suggested from this that 'well-being' merely provides a new way of describing economic development policy, without altering its fundamental logic or its inherent power relations.
\end{abstract}

Keywords: development; statistical measurement; metrics; well-being; Global South; reductionism; chaotic conception; universalism; power relations; structural inequalities.

Reference to this paper should be made as follows: Jenkins, M. (2016) 'Reasons to be cautious about 'well-being' in economic development (and elsewhere)', Int. J. Happiness and Development, Vol. 3, No. 2, pp.108-124.

Biographical notes: Matt Jenkins is a Researcher at the Centre for Urban and Regional Development Studies at the University of Newcastle. His research looks at how official statistics are constructed, with a particular focus on the Office for National Statistics' 'Measuring National Well-Being' programme.

\section{Introduction: 'Well-being' is a potential basis for development(s)}

"Understanding and improving well-being requires a sound evidence base that can inform policy-makers and citizens alike where, when, and for whom life is getting better." [Organisation for Economic Co-Operation and Development, (2013a), p.3]

“The challenge is to 'universalise' the framework for understanding well-being so that it is relevant for people in countries at all points on the development continuum, and then to define appropriate indicators that can capture and measure the multi-dimensional aspects of well-being in specific economic, cultural and social contexts." [Boarini et al., (2014), p.10] 
The concept of 'well-being', and the supportive use of programmes to measure it, is currently in vogue in the Global North. The policy discourses surrounding it have a strong emphasis on the limitations of GDP and the potential for alternatives to 'growth' as a measure of societal progress. In this it shares much in common with critiques of economic development which suggest that the focus on the Northern ideal of expanding market-based activities has negatively impacted on social conditions in the Global South. Promoters of the concept, such as the Organisation for Economic Co-operation and Development, are increasingly suggesting 'well-being' and its measurement as a means to achieving economic development (Boarini et al., 2014).

This paper argues that such a move is mistaken, and that the well-being movement shares more in common with existing approaches to economic development (and development more generally) than it does with their critique. The hope held out by the well-being movement is that merely by swapping one technocratic and reductionist measurement programme for another, differently reductionist, one, new ways of acting will become possible. This hope, if correctly characterised, rests on two implicit claims: that it is possible for a measurement programme to meaningfully encapsulate the concept of 'well-being', and that 'well-being' is not something which can be pursued (or, at least, is much less well pursued) in the absence of a measurement framework. It will be suggested that both these claims are mistaken. Rather, 'well-being' is a chaotic conception which cannot be meaningfully reduced to a closed set of indicators; and it is an aim which has historically underpinned interventions or justifications for interventions in both domestic and international economic development policy. As such, 'well-being' frameworks only offer a new language in which to talk about policy. This language is dangerous, masking the inequalities of power between the author of the framework and its subject. Rather than offering new ways for the Global South to articulate its ambitions, models of well-being risk being merely new technocratic ways to justify pre-existing rationales of intervention.

The paper proceeds as follows: the next section will briefly outline the features of well-being measurement frameworks as they currently exist in the Global North, observing that such frameworks necessarily reduce the question of 'well-being' to one of mechanical numerical movements and so are structurally identical to existing metrics. Section 3 will explore the nature of the concept of 'well-being', arguing that it is a 'chaotic conception' in Sayer's sense and thus one which precludes meaningful measurement (Sayer, 1981, 1982, 2000). Section 4 will then examine historic approaches to economic development, showing both that they already considered 'well-being' and that they could equally easily be justified using the contemporary rhetoric of well-being. In its concluding sections, the paper will suggest that reconceptualisation of 'well-being' as a technocratic tool merely recasts existing logics of economic development in a new language and that to take the concept of 'well-being' seriously it is necessary to go beyond measurement and towards dialogue with those whose 'well-being' is at issue.

\section{The technocratic nature of existing well-being frameworks}

'Well-being' is currently fashionable in policy circles in the Global North, giving rise to several major measurement programmes. Possibly most advanced is the UK's Measuring National Wellbeing Programme (currently with three years of published data; Office for 
National Statistics, 2013a, 2013b, 2014, 2015), and similar programmes or guidelines for programmes have been launched by Eurostat and the OECD (European Statistical System Committee, 2011; Organisation for Economic Co-Operation and Development, 2013a). Politically, the concept is well-supported, with the UK programme launched by the Prime Minister (Cameron, 2010) with cross-party support (New Economics Foundation, 2011), the European programme mandated by the Parliament, Commission and Economic and Social Committee (Commission of the European Communities, 2009; European Economic and Social Committee, 2012; European Parliament, 2011) and both the United Nations General Assembly (United Nations General Assembly, 2012) and G20 leaders (G20, 2009) issuing statements of support for the expanded collection of social indicators. The reach of the concept may be seen in signatories to the 'Istanbul Declaration' - the OECD, European Commission, Organisation of Islamic Conference, UN, UNDP and World Bank - who called on domestic statistical offices in member countries to develop their social indicators to allow better understandings of 'societal wellbeing' [Organisation for Economic Co-Operation and Development, (2007), p.1].

As a political discourse, 'well-being' is being used normatively; it is a good to be worked towards and secured. This is most apparent in Cameron (2010, np) who, quoting Robert Kennedy, notes that GDP "measures everything... except that which makes life worthwhile" [Kennedy, (1968), np]. "How we are doing as a nation", Cameron argues cannot be read from GDP alone; instead we should be counting whatever it is "that makes life worthwhile' (ibid., np). GDP stands as a description of market-based activities, which constitute only a small part of life, and treats these as an end in themselves, equating increased market-based activity with improved social outcomes. The suggestion of the well-being movement is that 'well-being' is a higher end than GDP, for which GDP is necessary but not sufficient. By going 'beyond GDP' (Commission of the European Communities, 2009) to directly measure aspects of the social, GDP can be resituated within political discourse as instrumental to 'well-being' rather than as constitutive of it (see also Organisation for Economic Co-Operation and Development, 2013b; United Nations General Assembly, 2012)

This normative argument is very closely bound up with ideas of 'development' or 'progress'. In launching the UK programme, Cameron claimed it to be a means of "measuring our progress as a country" by "how our lives are improving" [Cameron, (2010), np]; foregrounding development as the target of observations above and beyond GDP. The Istanbul Declaration goes further, affirming a "commitment to measuring and fostering the progress of societies in all their dimensions and to supporting initiatives at the country level"; the expanded framework of indicators beyond the merely economic being here both observer and facilitator of societal development [Organisation for Economic Co-Operation and Development, (2007), p.1].

In joining social indicators with 'progress', the well-being movement has an affinity with critiques of modes of development and economic development which are based around GDP growth, such as those posed by the 'post-development' literature (see for recent reviews of the field, Andrews and Dawa, 2014; McEwan, 2008). These critiques share the arguments of the well-being movement about the limitations of GDP, noting the harm and upheaval that economic development policies have had on populations in the Global South. By shifting away from GDP as an over-riding aim of policy, 'well-being' appears to open up space for theorists and practitioners to think about 'developments', of different ways of balancing economic, social and cultural aims, setting economic interventions in and on the Global South against locally determined needs and objectives. 
As such it stands as a both critique of the neoclassical economics which dominates economic development theory and practice (Fine, 2009) and of the underlying teleology and cultural superiority inherent in the concept of 'development' itself (Esteva, 1992).

It is, however, unlikely that the move to 'well-being' will lead to a move away from standard models of economic development. The reason for this is the gap between the normative aim of 'well-being' and the descriptive statistical frameworks proposed as aids to pursuing it. The political discourses of the Global North have resulted in a cluster of closely-related statistical programmes: in the UK, at European level and by the Organisation for Economic Co-Operation and Development (Eurostat, 2008; Office for National Statistics, 2014; Organisation for Economic Co-Operation and Development, $2013 \mathrm{~b}$ ). These programmes developed in dialogue with each other, sharing policy actors in their development (Bache, 2013; Bache and Reardon, 2013; Jenkins, 2016), and provide a structural model which is shaping efforts in other Northern nations and being promoted as a tool for Southern nations (see Boarini et al., 2014; Organisation for Economic Co-Operation and Development, 2013b). These programmes take the form of national aggregate dashboards, in which a series of measures taken at varying scales are aggregated to the national-level, producing a set of discrete indicators. This contrasts with the leading model from the Global South, Bhutan's 'Gross National Happiness' (see Ura et al., 2012), which sums indicators at the individual level, producing a national measure of how many individuals have or do not have 'well-being'.

In all four of these programmes (UK, European, OECD and Bhutanese), the abstract concept 'well-being' is constructed as a closed set of quantities, some of which are themselves concretisations of abstract concepts (such as 'happiness'). Like all reductionisms, it claims an equatability of qualities based on essential features. 'Well-being' is here a universal feature of nations (and its subcomponents are universal features of individuals) which exists independently of context, place, history, aims, values, structural conditions and inequalities: all of these are outside of 'well-being' and are relevant only in as far as they interact with measures which comprise it. The subject of 'well-being' is equally irrelevant: because 'well-being' is the same across nations; it does not matter to the framework who is doing well or ill, and how they are doing it is defined entirely in terms of the movement of quantities within the framework. This is particularly the case in the Northern frameworks, where national well-being is constructed of independent measures of well-being, and not of individuals with 'well-being'. 'Well-being' is not defined in relation to the particularities or experiential lives of individuals and collectives, but solely in generalities. Questions of who has ill-being, relative to what standards, and for what reason, lie outside of the framework's concerns.

At the same time, the multiplicity of sub-measures allows for a limited flexibility of conceptions: there may be multiple 'well-beings' read from the indicators of the framework. Nations are allowed to be happy but poor. However, these readings are limited by the contents of the framework. The poverty and the happiness are able to give context to each other, but stand divorced from any wider concerns. Beyond explanations in terms of statistical relations with each other, the why of the happiness or poverty is opaque. 'Well-being' becomes a matter of mechanical interactions between its components and only its components.

From this, all that appears to be being proposed in the movement towards 'well-being' measurement is a shift from one technocratic and reductive measurement 
framework to another. 'Well-being' is left with much the same structural logic as Escobar criticised in 'development', "a top-down, ethnocentric and technocratic approach, which treat[s] people and cultures as abstract concepts, statistical figures to be moved up and down in the charts of "progress" [Escobar, (1994), p.44]. The descriptive amount is being confounded with the normative good, and multiple potential ways of being are being collapsed into a small set of universal common 'well-beings' (Latouche, 1992).

\section{Well-being is a chaotic conception}

On the argument of the previous section, 'well-being' frameworks construct 'well-being' as an abstract but universal object, made up of other universal objects; as a construct which is equatable across contexts, made up of items equatable across contexts. Is 'well-being' amenable to such a construction? The present section will suggest that it is not: that 'well-being' is an evaluative state which cannot be defined independently of the aims and values of its holder and that attempts to do so produce a construction which is incoherent and unintelligible.

The first thing which suggests such a conclusion is the difficulty measurement frameworks have in specifying what the 'well-being' that they are measuring actually is. At the most abstract level, 'well-being' (as in Office for National Statistics, 2014) becomes 'quality of life' (as in Organisation for Economic Co-Operation and Development, 2013a) and 'progress' (as in United Nations General Assembly, 2012). These terms are nebulously defined: either by exclusion, as in the case of the European programme which seeks merely to 'go Beyond GDP' by measuring non-economic factors (Commission of the European Communities, 2009) or by reference to equally undefined or unspecified properties [Cameron (2010, np), for example, suggests that the well-being is a measure of, among other things, 'our quality of life', the thing which the OECD set out to measure specifically]. Often, there is no attempt at a definition at all: the UK Office for National Statistics' (ONS) Measuring National Well-Being programme aims at being "an accepted and trusted set of National Statistics which help people understand and monitor well-being", but does so through "looking at different areas of national well-being such as health, relationships, job satisfaction" [Office for National Statistics, (2014), p.52]. There is a definitional regress here, national well-being merely being the total of areas of national well-being, the concept being defined in terms of its shopping list of components. That is, what constitutes 'well-being' is whatever is thought to constitute 'well-being'; the abstract concept itself does not imply any definite qualities or abilities, so a concretised concept is stood in its stead.

The history of these conceptions gives some explanation of this vagueness. 'Well-being', in one form or another, has been a concern of philosophy since at least (in the Global North) the Ancient Greeks [Aristotle (1886) is often cited, particularly in justifying self-report measures of 'flourishing' as a 'well-being' component; see Allin and Hand, 2014]. This is a fact often observed by promoters of well-being as a way of grounding programmes or calls for programmes as being reasonable (see, for instance, O'Donnell et al., 2014), but what they tend not to note is that the debate was never resolved (White, 2006). Ideas of what constitutes a 'good', 'flourishing' or 'worthwhile' life (and it may be noted, again, a terminological vagueness and potential disagreement amongst such terms) still range widely, from the utilitarian principles of neoclassical economics (see Layard, 2005) to the deontological underpinnings of human rights theory 
(Griffin, 2008). While not showing that a definition is unachievable (although this, too, is a defensible philosophical position; see Rorty, 1980), this historic and ongoing lack of agreement at least suggests that opinions on the matter are liable to differ.

In research on 'well-being', there are at least six distinct constructs which appear across the literature as potential components. The most novel three in terms of measurement programmes come under the heading 'subjective well-being': self-report measures of positive and negative affect (normally happiness and anxiety), satisfaction with life and 'eudaimonia' (a consideration of whether life is 'fulfilling' or 'worthwhile'). These approaches are popular with economists who see them as a means of directly capturing utility independently of market activity, and so a means of pricing non-market interventions in terms of the 'satisfaction' they bring (see, particularly, Layard, 2005). It is worth noting, however, that there are three distinct constructs here - satisfaction, affectual condition and sense of fulfilment - which do not collapse in to each other (Diener and Seligman, 2004). It is also possible to ask for subjective evaluations of entire domains of human experience, such as 'society', or of external objects, such as 'the government'. This approach allows consideration of how individuals and collectives feel about their wider environment, whether they are in a world which is satisfying (Berger-Schmitt and Noll, 2000). Positive mental functioning has been distinguished from affect as a fifth construct, arguing that 'well-being' is about more than merely avoiding ill-being (Huppert et al., 2008; Stewart-Brown et al., 2011). Finally, there is what might be considered the traditional approach of observing and counting particular aspects of life, such as life expectancy or GDP. The Millennium Development Goals fit into this conception of well-being: areas selected for observation and intervention because they are seen as beneficial or harmful to the ability of individuals and collectives to live and function well (United Nations General Assembly, 2000).

That each of these six can sensibly fit into a conception of 'well-being' suggests that 'well-being' is something akin to 'doing well'. Such a broad construction, however, offers no limitation on what might be included; in the manner of the UK Office for National Statistics, above, it asks only for good things and the exclusion of bad things. But what counts as a 'good' or a 'bad' in this sense can only be defined relative to a set of aims and values; while there may be basic preconditions to 'doing well', such as being alive, these are minimal and themselves are subject to limitations connected with aims and objectives (that is, there may come a point where being alive is no longer a 'good' thing). Beyond this, any measures become profoundly ambivalent: even where there may be broad agreement about contribution to well-being (premature death or extreme poverty, for instance, are probably non-controversially detrimental to well-being), the point at which sufficiency is reached and, potentially, levels become harmful will be debated.

This is typified by the UK framework (Office for National Statistics, 2014), where a public debate provided a majoritarian underpinning for the general areas thought to comprise well-being (see Matheson, 2011) and the Office for National Statistics themselves selected mainly from existing and available statistics to 'fit' these areas. The result sees the public sector debt-to-GDP ratio sitting alongside inflation and real net national income per head in the 'economy' domain; three measures which will mean very different things to those of different aims, values and positions within society. The defined measurement set thus provides multiple objects; aims and values are mediating a large but limited number of possible 'well-beings' within the set. 
The critical realist Andrew Sayer's idea of a 'chaotic conception' is useful in describing the ambiguities and complexities which 'well-being' exhibits. Borrowing from Marx (1993), he defined a chaotic conception as an abstraction which groups together disparate and potentially contradictory aspects of the world into a single concept which appears to have unity and autonomous force [Sayer, (1982), p.72, 1981, 2000]. Such conceptions abound in the social sciences and, indeed, in this paper: 'economic development', for one, draws together ideas of wealth, integration in the world economy, industrial development, domestic infrastructure and so on (many of which, themselves, are chaotic catch-alls for disparate and uneven entities and concepts). Sayer argued that such conceptions were unhelpful, leading us to ask the wrong questions, questions about monoliths which were, ultimately, illusory. 'Well-being' is also a chaotic conception. In shifting from the abstract normative concept to the descriptive concretisation, the evaluative aspect of the concept has been lost. What was a judgement based on aims and values has become a judgement based on the movement of indicators with no theoretical linkages between them other than they are considered by the programme designers to be 'good' in some way.

To illustrate with a simple example: what are the relative well-beings of two nations, one with low GDP and high subjective well-being, the other with high GDP and low subjective well-being? It might be said that they both have room for improvement, so the question can be recast: at what point would an increase in GDP or subjective well-being be offset by a fall in the other? On what criteria would such a decision be based? The claim to 'well-being' is that there is something, 'well-being', which is changing with the movements of its components. So how is it changing? There is a difficulty here in the equation or relation of unlike measures within a single framework, which bodes ill for the use of well-being frameworks as a guide to action; it is not clear when an intervention would be necessary, or how it would balance against impacts on other measures. Extending this, there is a further difficulty in equating or relating unlike patterns of measurements across individuals and collectives. Any assessment made of the conditions of another is necessarily subjective, made from a particular standpoint of aims and objectives. A nation doing well by its own standards may not do well by those of another. Bhutan is a good example of this, with its focus on happiness in part in defiance of a persistently low level of GDP. Such problems of comparison make it difficult even to use frameworks to interpret the conditions of other nations, or to judge whether interventions have been 'successful' or not.

This chaos creates problems for the articulation of 'well-being' in a measurement framework. It was argued in the previous section that the framework reconstitutes the abstract notion of 'well-being' as a concrete, technical problem. But if the notion of 'well-being' is evaluative, and so is unintelligible independently of a particular set of aims and values, there can be no single framework or interpretation of a framework. This is as true within a nation or collective as it is between them. This leaves an inconsistency at the heart of the measurement frameworks: as multi-item sets, they allow that there are multiple ways in which an individual or collective can thrive, but, at the same time, they set boundaries on which ways are permissible. In doing so, they accept a multiplicity of views while ruling some views out of bounds. The promise held out by the measurement framework is thus unachievable: 'well-being' as an abstract evaluative state can only be reduced to a set of quantities at the expense of ignoring its evaluative nature and so ignoring at least some of its components. Whatever a nation, collective or individual believes 'well-being' to be (if, in fact, they have such a conception), they are offered the 
inter-relation of a small number of concrete measures, as determined by the author of the framework. It should be noted that this is true no matter what measures are included, and would be as true of a framework based around, for example, Sen's capabilities (Sen, 1989), as it is of the Northern frameworks discussed.

To answer the question of how well-being measurement may influence economic development policy, then, first it needs to be asked whose conception of well-being will be measured. Whose interests and pre-conceptions will be reflected? And who will determine how the pattern of measures will be interpreted?

\section{The concept of 'well-being' is not novel in economic development policy or practice}

The argument above may be accepted, but felt to be doing too much. 'Well-being' may be indefinable, and the measurement sets around it at best approximations, but the latter may still be helpful in establishing alternative aims and objectives as being on a par with economic concerns such as GDP growth. On this reading, it does not matter that 'well-being' cannot be fully captured; the fact that it is now being considered at all within policy is a step forward. The existence of frameworks ensures a salience for matters like subjective well-being which they previously did not have, allowing the impact of economic development policy to be more fully considered.

Such a hope is simultaneously over-optimistic and over-pessimistic. Its pessimism stems from the implicit claim that well-being is not something already considered by policy makers and others involved in economic development. As Fujiwara and Campbell (2011) observed, writing for the UK Treasury to defend their incorporation of 'well-being' into government cost-benefit analyses, this is not the case. The focus on growth, both in the Global North and in its economic development policies, is predicated on the assumption that growth is a good thing instrumentally, that it will improve the lives who live under it. Nor was growth an overriding aim: governments were aware of non-economic metrics of human life and capable of balancing them against longer-term aims of economic development. This can be seen in the prior existence of social statistics which new well-being frameworks have joined together, and in initiatives such as the Millennium Development Goals. Policy makers were concerned with well-being, even if they were not formally labelling and tracking it as such. If this is true, though, there is reason to doubt the optimism of the claim: if policy makers and other developers already considered well-being in some form yet still produced the policies they have done, what difference would a formal framework make?

To put this question another way: would the existence of well-being frameworks have changed previous schemes for economic development? The case can be made that they would not, using the history of actually existing schemes such as structural adjustment policies (SAPs) and their successors, poverty reduction strategy papers (PRSPs). These two sets of interventions act as good test cases of the limitations of 'well-being' in shaping policy: not only have they been the largest and most systematic economic intervention by the Global North in the Global South in the 35-or-so years since they were first developed, but they are accompanied by a wealth of research showing that they are actively harmful to what is now being considered 'well-being'. Numerous studies have noted declines in levels of health (de Vogli, 2011; Hoddie and Hartzell, 2014), 
increases in infant mortality (Coburn et al., 2015; Shandra et al., 2012) and maternal mortality (Pandolfelli et al., 2014), reduction in the status and freedoms of women (Summerfield and Aslanbeigui, 1998), reductions in access to human rights (Abouharb and Cingranelli, 2009), and growth in inequality (Oberdabernig, 2013) related to the imposition of SAPs and PRSPs. These harms fall most heavily on the most vulnerable: van de Walle (2001), for instance, shows how adjustment policies have been implemented in sub-Saharan Africa in such as way as to secure the position of elites even as they damage the interests of broader societal groups. Such studies suggest a great potential for a well-being framework: had these harms been visible, as they would have been if tracked in national 'well-being' programmes, the policy may have been adjusted.

The problem with such an argument is that the harms were visible (Jolly, 1991). Vetterlein (2008) and Grawe (2013) in their histories of SAPs note that international finance institutions were aware of these criticisms, but that their initial reactions was to deny the relevance of these harms: at best, they were short-term blips on the road to a better future, at worst they were irrelevant, outside the aims and scopes of the economic development project. Such an argument could still be made in the context of a well-being framework: witness the programmes of austerity which have run alongside the development of well-being frameworks in the Global North, programmes which are predicated on ideas of pain now to avoid more pain later [indeed, Cameron $(2010, \mathrm{np})$ is keen to emphasise that well-being will not prove a distraction from austerity].

The political pressure deepened in the early 1990s, with the UN Development Programme moving to establish a set of objective measures of well-being in the form of the Human Development Index (Jolly, 1991). While this led to the World Bank and, later, International Monetary Fund relaxing somewhat their restrictions on the provision of social safety nets, the macro-economic policies, and the damage they caused, were left fundamentally unchanged. When the structural adjustment programmes were overhauled in the late 1990s, it was not because of the substantial body of evidence of the harms they caused, but because they appeared not to work on their own terms (World Bank, 1996).

Their replacements, PRSPs, have fared little better. As Dijkstra (2011), Fraser (2005), Lazarus (2008) and Levinsohn (2003) have noted, the promise that these would be participatory projects in which recipient governments would shape the structural adjustment they would undertake has not been met. While there has been some local input into sectoral and micro-economic plans, the macro-economic outlines of the programmes are the same as under the SAP regime (Guimarães and Avendaño, 2011). The only real difference between the two is that 'participation' now accompanies 'development' and 'poverty' as a neutrally constructed universal, subject to technical solutions (Cornwall and Brock, 2005).

This story of economic development and social harm has been played out across the Global South. To take an example, Ghana entered its first structural adjustment plan in 1983 under the military dictatorship of Jerry Rawlings. Partly due to the increased scope the authoritarian regime had relative to democratic governments, the plan was implemented more-or-less faithfully and Ghana quickly became seen as a SAP success story (Konadu-Agyemang, 2001a). It largely achieved its aims of economic growth, reduced inflation and reduced government expenditure. However, it did so at the cost of turning Ghana into a 'neocolonial economy' [Dzorgbo, (2001), p.291], marked by high unemployment and under-employment (Konadu-Agyemang, 2001a), declining human capital as health and education services were taken out of the financial reach of most citizens, environmental despoilation as the economy oriented itself around primary 
resource extraction (Donkor, 1997), increased child labour (Hutchful, 2002), rural poverty (Weissman, 1990) and urban housing affordability issues (Konadu-Agyemang, 2001b). These social problems were apparent beyond the academic literature. In 1988, they were sufficient that an anti-poverty programme was introduced, explicitly as a palliative; the regime agreed it only when additional external funding could be secured from international donors and on the condition that no changes would be made to the implementation of the SAP. The half-heartedness of this programme, and the weakness of its achievements, led one commentator to describe it as "a gargantuan political fraud inflicted on the people of Ghana by the government and its international backers" [Donkor, (1997), pp.239-240].

\section{5 'Well-being' as a 'fuzzword'}

As a final attempt to salvage well-being frameworks, it could be argued that, regardless of what measure is finally targeted, the presence of a framework which includes even basic measures of the social beyond the economic provides the space to discuss and debate priorities. For instance, by tracking subjective well-being alongside GDP, it is possible to make the argument that GDP should not be the aim of policy, or that it should be approached in a different way.

There are a number of reasons why we might be cautious of this. One is the position of the Millennium Development Goals discussed above: it is already possible to talk about the impacts of economic policy on lives in the Global South, there is a specialised and highly visible framework to allow it, and it has not led to a change in macro-economic policy at the level of institutional lenders despite such policies potentially impeding the development goals (Fehling et al., 2013). It is hard to believe that such aims will become any more of a priority when grouped alongside economic measures; rather this would seem to equate the economic and the non-economic, encouraging an assessment of the social in economic terms. At the same time, the privileging of particular measures within a framework limits the visibility of measures left out of the framework making it harder to talk about, for instance, structural or contextual concerns such as the justice of international debt or trade relations, or histories of colonial and neo-colonial exploitation.

More pressing, however, is the track record of other normative concepts that have been brought into the wider development discourse. Cornwall and Brock (2005) examine a number of similarly abstract 'fuzzwords' in contemporary development discourse ('poverty reduction', 'participation', 'empowerment') arguing that their usefulness to policy makers arises from their ability to hide multiple meanings inside an unimpeachable normative container. They establish universal, but ill-defined (I would say 'chaotic') concepts, which are as hard to oppose as they are to specify. That difficulty in opposition transfers to the expression of the vague universal; 'poverty reduction' as expressed is protected because no one can oppose 'poverty reduction' in principle. 'Wellbeing' acts in exactly the same way. The rhetoric of well-being, the sentiment behind it, is almost impossible to oppose; such opposition would stand as a claim that people should be worse off. A well-being framework, however, is not the abstract sentiment but a particular expression of it: the technocratic measurement of aspects of life masquerading as a universal and placeless principle. 
The result of this may not be to provide us with new ways of talking about harm, and thus ways of securing 'well-being', but new ways of recasting harm as positive. An old example of this sort of linguistic slight-of-hand can be seen in Article 22 of the Covenant of the League of Nations which justified the colonial rule by Northern powers of peoples formerly ruled by the Ottomans on "the principle that the well-being and development of such peoples form a sacred trust of civilisation" (Manley, 1931). The explicit link here between 'well-being' and 'development' prefigures that of modern frameworks, and utilises both to justify the extension of regimes of paternalistic expropriation and oppression (itself recast as 'civilisation'). The inequality of power between the subject and the ruling nations, and any difference in definition as to what constitutes 'well-being', is obscured by the appeal to universal principals.

Contemporaneously, we can see a similar process in Bhutan, whose policy of Gross National Happiness is fêted in policy and academic circles for 'doing development differently' (for a typical paean, see Burns, 2011). Over the last 20 years, Bhutan's economy has increased in size, in part because of the development of a hydro-electric power sector in the South of the country. This has been accompanied by the systematic oppression of the ethnic Nepalese minority who live in the south: starting with an anti-miscegenation law, the Marriage Act of 1980, the Nepalese have been denied citizenship, deported or harried out of the country, denied the right to educate their children in their own language, denied cultural autonomy in their dress and denied access to much of the labour market and most state benefits; at one point an estimated 140,000 lived in refugee camps in Nepal and India (Human Rights Watch, 2007; for a more recent figure, which takes into account refuge settlement outside of Bhutan, see UNHCR, 2016; see also Rizal, 2004; de Varennes, 2008). This oppression has run alongside the better-advertised policy of Gross National Happiness. Not only does Gross National Happiness act as marketing which distracts attention from this policy of ethnic cleansing, it is tied to it: one of the programme's indicators relates to homogeneity of cultural identity, meaning that an improvement in the index comes at the direct expense of the Nepalese who must assimilate (a task made more difficult by denial of citizenship and restrictions on access to civil society) or leave. The rhetoric of well-being and the high-level of the programme serve to both hide and justify oppression. In the same way as the SAP, the harm is already considered permissible, 'well-being' gives a new way in which to talk about it.

This example may be considered extreme, but in light of the discussion above we might consider other questions elided by the Gross National Happiness framework. When the measurement was introduced in 1972, and for the subsequent 36 years, the country was an autocracy, offering little or no democratic freedom to its population. Speaking in 2013, the newly elected Prime Minister highlighted a number of areas from which Gross National Happiness was something of a 'distraction': “our ballooning debt that if we're not careful will not be sustainable; the big rupee shortage; unemployment, in particular youth unemployment; and a perception of growing corruption" [Tobgay, quoted in BBC (2013)]. Neither Bhutan's programme nor those in the Global North consider suicide: the World Health Organisation suggests that Bhutan's rate, 17.8 per 100,000 people in 2012, is one of the highest in the world (World Health Organisation, 2016; the rate for refugees from Bhutan to the USA, 21.5, and in refugee camps, 20.7, are even higher; Centre for Disease Control, 2013). It is not my purpose here to suggest that measures of democratic engagement, debt, unemployment, perceptions of corruption or suicide should be taken as measures of 'development', 'progress' or 'national success', nor to suggest that 
'well-being' frameworks should include them. The point here is that these, on the account of Gross National Happiness, are not to do with happiness, the success of the nation, or anything else. They are not counted, and they do not count. The existence of the framework is limiting what can be talked about.

Fuzzwords of Cornwall and Brook's kind suggest that problems and their solutions are neutral: there is 'well-being' and it can be brought about through a balancing of policies. However, as they argue (2005, p.1056), "the terms we use are never neutral": there is a power-relation between the person who gets to define the concept and the one who has that definition imposed on them. The statistic is never neutral either. It, too, reflects a series of power relations and decisions about who gets counted, what aspects of their lives are counted, what weight is given to those aspects, and so on. It is necessarily reductive, and decisions are made about what is left out. However, it stands as a statement of what is: just as GDP is blind to happiness, the national levels of well-being are blind to anything outside of the measures they include. These are not counted, and do not count. Similarly, they are largely blind to distributional issues: unless specifically observed, the variations in levels according to scale, location, gender, ethnicity, class, social grouping, and so on are lost in a national picture. They are not counted, and do not count.

This is true not only in the Global South, but more generally. As Gaventa (1998) points out, the 'North' is no more homogeneous than the 'South' is, it has its regions of historically and structurally-determined and -enforced disadvantage. These are the areas in which well-being is arguably normatively most pressing; areas of vulnerable people, deprived of access to the labour market, to amenities, to state services, with lower life expectancies, higher morbidity, lower educational levels. These are all areas counted by Northern well-being frameworks, but they are also all areas which were counted prior to the well-being frameworks existing. The existence of the framework does not change the power relations between these subaltern populations and the markets and states they exist within and alongside. In many cases, the framework acts to further marginalise populations, by burying their pockets of ill-being beneath bland national averages.

It is this model which we are considering when asking whether well-being measurement can bring better economic development. It should be clear that any hope that a move away from GDP might lead to development based around the desires and needs of Global South is unlikely to be achieved in this way. The statistical logic of measurement does not interfere with the model logic of economic development or of development more generally. It does not challenge the power relations inherent in the development process, particularly where 'development' and 'well-being' are being defined by the same people, as they currently are in the Global North (and, as I write this, I am painfully aware of the fact that I am a scholar from the Global North, writing in a journal in the Global North, about whether we can or should extend our current pet epistemology to the Global South. Who are we to ask such questions?).

\section{Conclusions: taking well-being seriously means not counting it}

This paper has argued that the measuring of 'well-being' necessarily misdefines it, attempting to separate an evaluative state from the grounds of its evaluation, compressing it into the statistical interaction of meaning-free metrics. In doing so, it produces an 
unresolvable melange of measures, open and liable to determination by those holding power. It also produces a rhetorical language which obscures and justifies the conduct of that power.

This may feel something of an extreme conclusion, given the normative force of 'well-being' as a concept. However, if that normative force is to be taken seriously, there needs to be a less mediocre response than merely counting discrete aspects of human existence and attempting to relate them statistically. What 'well-being' offers is an indication of the inherent contradiction of social statistics: that they can operate only by reducing the social to the mechanical. If the social is the object of interest, as 'well-being' movement suggests it should be, there needs to be a social way of examining it. To take 'well-being' seriously there needs to be dialogue which addresses the complex grounds on which the assessment of 'well-being' is being made. As a starting point, that is going to mean talking to those in the Global South about how they conceptualise their 'well-being', and about how this interacts with their hopes for 'development'; moving away from models of concrete and defined universals and towards richer, narrative accounts.

One potential model for such work is 'participatory development', in the sense discussed by Hickey and Mohan (2005). Reviewing earlier work, they suggested that much which went under the name of 'participation' was technocratic, top-down and exclusionary in the manner of PRSPs discussed above, with 'participation' serving as another fuzzword obscuring Northern interventionism (Cornell and Brook, 2005). They argue that for participatory development to be successful, it needs to be grounded in notions of citizenship which extends democratic access to marginalised groups. Such a conception is broader than the teleological conception of 'development' and 'progress' implied by technocratic measurement frameworks, recognising those who are to 'progress' as individuals with agency. As such agency encompasses views about 'well-being', participatory approaches provide a potential alternative starting point to build developments which take well-being seriously.

\section{Acknowledgements}

The author is funded by the ESRC, grant number ES/J50082/1. My gratitude and thanks to Andy Pike, Joe Painter and, particularly, Mike Coombes for their constructive comments on earlier versions of this paper. I am also very grateful for the attention of Parviz Dabir-Alai and three anonymous reviewers, whose contributions improved the submitted version of the text. Any errors or omissions that remain I claim for myself.

\section{References}

Abouharb, M.R. and Cingranelli, D.L. (2009) 'IMF programs and human rights, 1981-2003', Review of International Organizations, Vol. 4, No. 1, pp.47-72.

Allin, P. and Hand, D.J. (2014) The Wellbeing of Nations; Meaning, Motive and Measurement, John Wiley and Sons, Oxford.

Andrews, N. and Dawa, S. (2014) 'A post-development hoax? (Re)-examining the past, present and future of development studies', Third World Quarterly, Vol. 35, No. 6, pp.922-938.

Aristotle (1886) The Nichomachean Ethics of Aristotle, Kegan Paul, Trench \& Co., London. 
Bache, I. (2013) 'Measuring quality of life for public policy: an idea whose time has come? Agenda-setting dynamics in the European Union', Journal of European Public Policy, Vol. 20, No. 1, pp.21-38.

Bache, I. and Reardon, L. (2013) 'An idea whose time has come? Explaining the rise of well-being in British politics', Political Studies, Vol. 61, No. 4, pp.898-914.

BBC (2013) Bhutan PM Casts Doubts over Gross National Happiness [online] http://www.bbc.com/news/world-asia-23545641 (accessed 13 February 2016).

Berger-Schmitt, R. and Noll, H-H. (2000) Conceptual Framework and Structure of a European System of Social Indicators, Centre for Survey Research and Methodology, Mannheim.

Boarini, R., Kolev, A. and McGregor, A. (2014) Measuring Well-Being and Progress in Countries at Different Stages of Development: Towards a More Universal Conceptual Framework, OECD, Paris.

Burns, G. (2011) 'Gross National Happiness: a gift from Bhutan to the world', in Biswas-Diener, R. (Ed.): Positive Psychology as Social Change, pp.73-87, Springer Netherlands, Dordrecht.

Cameron, D. (2010) PM Speech on Wellbeing [online] http://www.number10.gov.uk/news/pmspeech-on-well-being/ (accessed 22 October 2012).

Centre for Disease Control (2013) Suicide and Suicidal Ideation among Bhutanese Refugees United States, 2009-2012 [online] http://www.cdc.gov/mmwr/preview/mmwrhtml/ mm6226a2.htm (accessed 13 February 2016).

Coburn, C., Restivo, M. and Shandra, J.M. (2015) 'The African Development Bank and infant mortality: a cross-national analysis of structural adjustment and investment lending from 1990 to 2006', International Journal of Comparative Sociology, Vol. 56, Nos. 3-4, pp.275-296.

Commission of the European Communities (2009) GDP and Beyond: Measuring Progress in a Changing World, Commission of the European Communities, Brussels.

Cornwall, A. and Brock, K. (2005) 'What do buzzwords do for development policy? A critical look at 'participation', 'empowerment' and 'poverty reduction', Third World Quarterly, Vol. 26, No. 7, pp.1043-1060.

de Varennes, F. (2008) 'Constitutionalising discrimination in Bhutan: the emasculation of human rights in the Land of the Dragon', Asia-Pacific Journal on Human Rights and the Law, Vol. 9, No. 2, pp.47-76.

de Vogli, R. (2011) 'Neoliberal globalisation and health in a time of economic crisis', Social Theory and Health, Vol. 9, No. 4, pp.311-325.

Diener, E. and Seligman, M.E. (2004) 'Beyond money; toward an economy of well-being', Psychological Science in the Public Interest, Vol. 5, No. 1, pp.1-31.

Dijkstra, G. (2011) 'The PRSP appraoch and the illusion of improved aid effectiveness: lessons from Bolivia, Honduras and Nicaragua', Development Policy Review, Vol. 29, No. s1, pp.s111-s133.

Donkor, K. (1997) Structural Adjustment and Mass Poverty in Ghana, Ashgate, Aldershot.

Dzorgbo, D.S. (2001) Ghana in Search of Development: The Challenge of Governance, Economic Management and Institution Building, Ashgate, Aldershot.

Escobar, A. (1994) Encountering Development: The Making and Unmaking of the Third World, Princeton University Press, Princeton, NJ.

Esteva, G. (1992) 'Development', in Sachs, W. (Ed.): The Development Dictionary: A Guide to Knowledge as Power, pp.6-25, Zed Books, London.

European Economic and Social Committee (2012) 'Opinion of the European Economic and Social Committee on 'GDP and beyond - the involvement of civil society in choosing complementary indicators' (own-initiative opinion)', Official Journal of the European Union, C 181/04, pp.14-20.

European Parliament (2011) GDP and Beyond - Measuring Progress in a Changing World: Resolution of 8 June 2011, European Parliament, Brussels. 
European Statistical System Committee (2011) Sponsorship Group on Measuring Progress, Well-Being and Sustainable Development: Final Report, ESSC, Luxembourg.

Eurostat (2008) Feasibility Study for Well-Being Indicators: Task 4: Critical Review, Eurostat, Luxembourg.

Fehling, M., Nelson, B.D. and Venkatapuram, S. (2013) 'Limitations of the millennium development goals: a literature review', Global Public Health, Vol. 8, No. 10, pp.1109-1122.

Fine, B. (2009) 'Development as zombieconomics in the age of neoliberalism', Third World Quarterly, Vol. 30, No. 5, pp.885-904.

Fraser, A. (2005) 'Poverty reduction strategy papers: now who calls the shots?', Review of African Political Economy, Vol. 32, Nos. 104-105, pp.317-340.

Fujiwara, D. and Campbell, R. (2011) Valuation Techniques for Social Cost-Benefit Analysis: Stated Preference, Revealed Preference and Subjective Well-Being Approaches; A Discussion of the Current Issues, HM Treasury, London.

G20 (2009) G20 Leaders' Statement: The Pittsburgh Summit [online] http://www.g20.utoronto.ca/ 2009/2009communique0925.html (accessed 4 June 2014).

Gaventa, J. (1998) 'Poverty, participation and social exclusion in north and south', IDS Bulletin, Vol. 29, No. 1, pp.50-57.

Grawe, R. (2013) Innovation at the World Bank: Selective Perspectives over Three Decades 1975-2005, UNI World Institute for Development Economic Research, Helsinki.

Griffin, J. (2008) On Human Rights, Oxford University Press, Oxford.

Guimarães, J.P. and Avendaño, N. (2011) 'The great experiment: testing the PRSP approach in Nicaragua, 2000-2007', European Journal of Development Research, Vol. 23, No. 2, pp.319-336.

Hickey, S. and Mohan, G. (2005) 'Relocating participation within a radical politics of development', Development and Change, Vol. 36, No. 2, pp.237-262.

Hoddie, M. and Hartzell, C.A. (2014) 'Short-term pain, long-term gain? The effects of IMF economic reform programs on public health performance', Social Science Quarterly, Vol. 95, No. 4, pp.1022-1042.

Human Rights Watch (2007) Last Hope: The Need for Durable Solutions for Bhutanese Refugees in Nepal and India, Human Rights Watch, New York.

Huppert, F.A., Marks, N., Clark, A. et al. (2008) Measuring Well-Being across Europe: Description of the ESS Well-Being Module and Preliminary Findings, Paris School of Economics, Paris.

Hutchful, E. (2002) Ghana's Adjustment Experience: The Paradox of Reform, United Nations Research Institute for Social Department, Geneva.

Jenkins, M. (2016) Understanding Official Statistic-Making as a Social Process: The UK 'Measuring National Well-being' Programme, Unpublished $\mathrm{PhD}$ thesis, University of Newcastle.

Jolly, R. (1991) 'Adjustment with a human face: a UNICEF record and perspective on the 1980s', World Development, Vol. 19, No. 12, pp.1807-1821.

Kennedy, R.F. (1968) Remarks at the University of Kansas, 18 March [online] http://www.jfklibrary.org/Research/Research-Aids/Ready-Reference/RFK-Speeches/Remarksof-Robert-F-Kennedy-at-the-University-of-Kansas-March-18-1968.aspx (accessed 7 April 2013).

Konadu-Agyemang, K. (2001a) 'Africa under World Bank/IMF management: the best of times and the worst of times', inKonadu-Agyemang, K. (Ed.): IMF and World Bank Sponsored Structural Adjustment Programs in Africa: Ghana's Experience, 1983-1999, pp.427-434, Ashgate, Aldershot.

Konadu-Agyemang, K. (2001b) 'Structural adjustment programs and housing affordability in Accra, Ghana', The Canadian Geographer, Vol. 45, No. 4, pp.528-544. 
Latouche, S. (1992) 'Standards of living', in Sachs, W. (Ed.): The Development Dictionary: A Guide to Knowledge as Power, pp.250-263, London.

Layard, R. (2005) Happiness: Lessons from a New Science, Penguin, London.

Lazarus, J. (2008) 'Participation in poverty reduction strategy papers: reviewing the past, assessing the present and predicting the future', Third World Quarterly, Vol. 29, No. 6, pp.1205-21.

Levinsohn, J. (2003) The World Bank's Proverty Reduction Strategy Paper Approach: Good Marketing or Good Policy?, United Nations, New York.

Manley, O. (1931) International Legislation: A Collection of the Texts of Multipartite International Instruments of General Interest, Beginning with the Covenant of the League of Nations, Carnegie Endowment for International Peace, Washington, DC.

Marx, K. (1993) Grundrisse: Foundations of the Critique of Political Economy, Penguin, London.

Matheson, J. (2011) Measuring National Well-Being: Measuring What Matters - National Statistician's Reflections on the National Debate on Measuring National Well-Being, Office for National Statistics, London.

McEwan, C. (2008) Postcolonialism and Development, Taylor and Francis, Hoboken, NJ.

New Economics Foundation (2011) The Practical Politics of Well-Being, NEF, London.

O’Donnell, G., Deaton, A., Duran, M. et al. (2014) Wellbeing and Policy, Legatum Institute, London.

Oberdabernig, D.A. (2013) 'Revisiting the effects of IMF programs on poverty and inequality', World Development, Vol. 46, pp.113-142.

Office for National Statistics (2013a) Personal Well-Being across the UK, 2012/13, ONS, London.

Office for National Statistics (2013b) Personal Well-Being in the UK, 2012/13, ONS, London.

Office for National Statistics (2014) Measuring National Well-Being: Life in the UK, 2014, HMSO, London.

Office for National Statistics (2015) Personal Well-Being in the UK, 2014/15, HMSO, London.

Organisation for Economic Co-Operation and Development (2007) Istanbul Declaration, OECD, Istanbul.

Organisation for Economic Co-Operation and Development (2013a) OECD Guidelines on Measuring Subjective Well-Being, OECD, Paris.

Organisation for Economic Co-Operation and Development (2013b) Measuring Well-Being and Progress, OECD, Paris.

Pandolfelli, L.R., Shandra, J. and Tyagi, J. (2014) 'The international monetary fund, structural adjustment, and women's health: a cross-national analysis of maternal mortality in Sub-Saharan Africa', The Sociological Quarterly, Vol. 55, pp.119-142.

Rizal, D. (2004) 'The unknown refugee crisis: explusion of the ethnic Lhotsampa from Bhutan', Asian Ethnicity, Vol. 5, No. 2, pp.151-177.

Rorty, R. (1980) 'Pragmatism, relativism, and irrationalism', Proceedings and Addresses of the American Philosophical Association, Vol. 53, No. 6, pp.719-738.

Sayer, A. (1981) 'Abstraction: a realist interpretation', Radical Philosophy, Vol. 28, pp.6-15.

Sayer, A. (1982) 'Explanation in economic geography: abstraction versus generalization', Progress in Human Geography, Vol. 6, No. 1, pp.68-88.

Sayer, A. (2000) Realism and Social Science, Sage, London.

Sen, A.K. (1989) 'Development as capability expansion', Journal of Development Planning, Vol. 19, No. 1, pp.41-58.

Shandra, C.L., Shandra, J.M. and London, B. (2012) 'The International Monetary Fund, structural adjustment, and infant mortality: a cross-national analysis of Sub-Saharan Africa', Journal of Poverty, Vol. 16, No. 2, pp.194-219. 
Stewart-Brown, S.L., Platt, S., Tennant, A. et al. (2011) 'The Warwick-Edinburgh mental well-being scale: a valid and reliable tool for measuring mental well-being in diverse populations and projects', Journal of Epidemiology and Community Health, Vol. 65, No. Sup. 2, pp.A38-A39.

Summerfield, G. and Aslanbeigui, N. (1998) 'The impact of structural adjustment and economic reform on women', in Stromquist, N.P. (Ed.): Women in the Third World: An Encylopedia of Contemporary Issues, pp.332-340, Garland Publishing, New York.

United Nations General Assembly (2000) United Nations Millennium Declaration. Resolution Adopted by the General Assembly on 8 September 2000, UN General Assembly, New York.

United Nations General Assembly (2012) The Future We Want. Resolution Adopted by the General Assembly on 27 July 2012, UN General Assembly, New York.

UNHCR (2016) Nepal Factsheet [online] http://www.unhcr.org/cgi-bin/texis/vtx/home/ opendocPDFViewer.html?docid=50001f3c9\&query=bhutan\%20nepal (accessed 5 May 2016).

Ura, K., Alkire, S., Zangmo, T. and Wangdi, K. (2012) An Extensive Analysis of GNH Index, Centre for Bhutan Studies, Thimphu, Bhutan.

van de Walle, N. (2001) African Economies and the Politics of Permanent Crisis 1979-1999, Cambridge University Press, Cambridge.

Vetterlein, A. (2008) Lacking Ownership: the IMF and Its Engagement with Social Development as a Global Policy Norm, Copenhagen Business School, Copenhagen.

Weissman, S.R. (1990) 'Structural adjustment in Africa: insights from the experiences of Ghana and Senegal', World Development, Vol. 18, No. 2, pp.1621-1634.

White, N. (2006) A Brief History of Happiness, Blackwell Publishers, Oxford.

World Bank (1996) World Bank Participation Sourcebook, The World Bank, Washington, DC.

World Health Organisation (2016) Age-Standardised Suicide Rater (per 100,000), dataset [online] http://apps.who.int/gho/data/view.main.MHSUICIDEv (accessed 13 February 2016). 